\title{
Biucds
}

\section{Of the Same Feather}

\section{Shaul Fly Together}

\author{
A SUPPLEMENTARY READING MANUAL \\ FOR STUDENTS OF \\ ADVANCED ENGLISH CLASSES
}

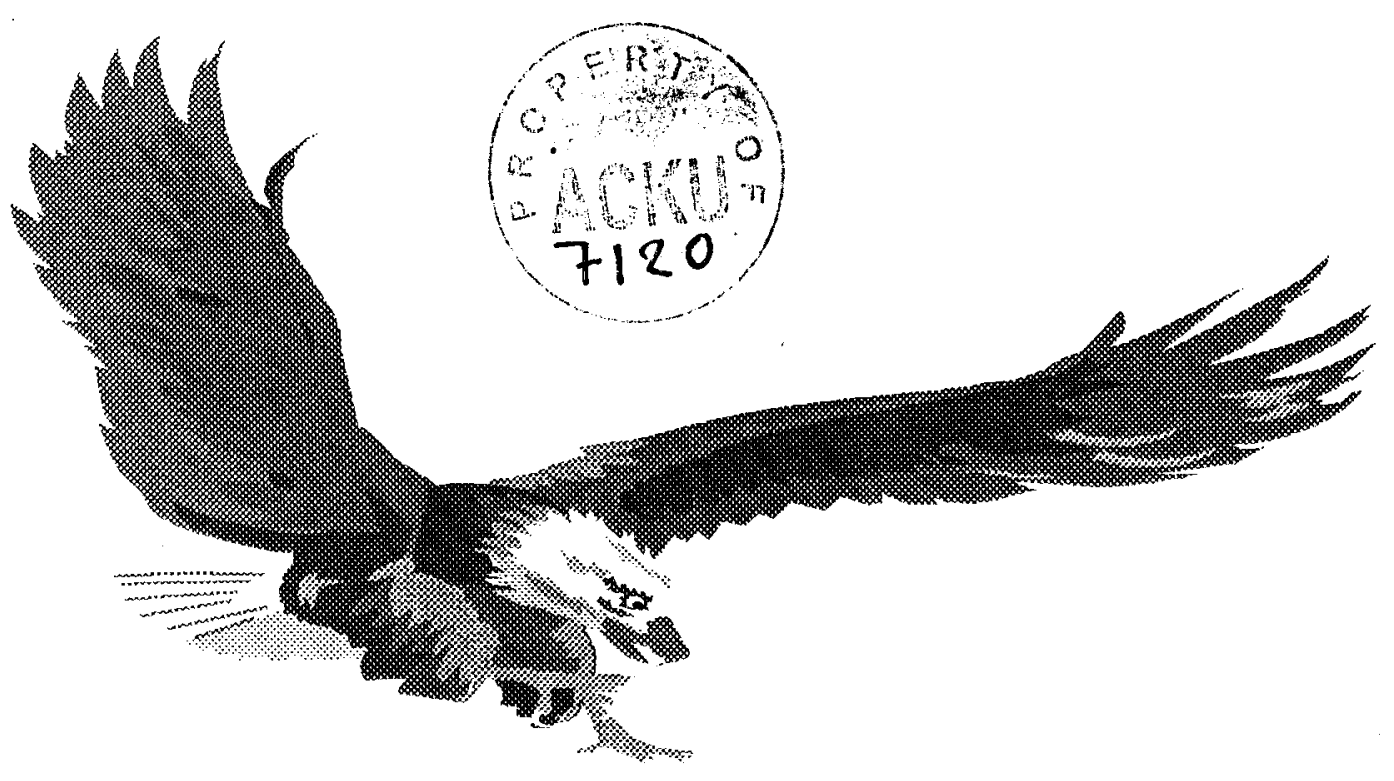

By: G.A. Eqbal

Specialist Degree In Education Ball State University USA 


\section{About the Book}

- This book targets Afghan Teenagers who like to learn English as second language. At this level they read in their courses books written mostly by native speakers .

- Easy reading material with intermediate vocabulary written by an Afghan, helps your reading skills both in speed and comprehension. It also helps your passive vocabulary to become active.

- The story of Y.E. a village boy who is serious about his school and in his own explorations in life, but caught in parental pre-mature plans, serves as an eye opener for young boys and girls to be alert towards problems and challenges in life while taking advantage of their God given rights \& freedoms, as well as paying sound respect to their parents.

- The book is based on a real story taken place in Afghanistan in 1960s.

- Youth are full of talents yet to be developed. The story helps them to choose their future model, Chicken or Eagle .

- If they choose to be an eagle then they must develop the right wings and expand their vision and horizon in life via education.

- Many parents have seen children keeping little bird in their hands so tight that the poor bird could not breath. When they open their hands they find a dead bird at their palms. Then they begin crying.

- It is amazing that many boys and girls fall at the palm of parents just like little birds which can not communicate back the pressures suffocating them.

- The book conveys one message to both the parents and the children not to fall in that tricky situation. In other words: Don't suffocate them, Let them live.

\section{Eqbal}

Peshawar,1998

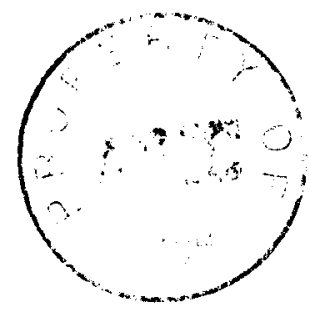




\section{CHAPTER ONE \\ Childhood}

$\mathrm{O}$

nce upon a time there was an eagle. The eagle flew all day long from mountain to mountain and from one valley to another. He flew high in the sky and spotted his prey miles bellow in the air, land or water. Then he beamed him self down and dashed swiftly towards it's prey just like a bullet shot from a gun with binocular. The eagle quickly grasped it's prey and flew back to the sky and to the peaks of the mountains with the prey in his claws

His elderly parents who couldn't fly that high any more, decided to arrange the marriage of the eagle with an owl so that they both stay much often to the low lands in the valley where the parents had lived and had plenty of land and a lot of peasants from turkey, chicken and the dodo families working in their fields and gardens

Poor parents didn't live long to see the marriage and their grand children, however, the owl and the eagle had two cute little baby eagles both of which died one after another from cold. Because the father spent much of his time away from home up in the high mountains and when the mother owl went for hunt, the babies caught cold in the high tree where they had nested and the chickens the turkeys and dodos couldn't do much about it.

Father eagle came home occasionally and unexpectedly and further more no one knew how long he was going to stay as he was traveling all year round. Soon appeared the third baby. Both the father and mother owl were very happy about it. They both promised to stick around till the baby was big enough to fly and hunt by himself without parental support.

Baby eagle was growing faster and becoming bigger and bigger every day and both parents were taking good care of him. Soon baby eagle turned to a handsome and strong Young Eagle (YE). Mother owl was very happy because YE though fairly strong, didn't disappear like his father. YE was often hunting together with mother and ate together in the nest

Occasionally YE and mother went up to the high mountains where they could find the father and after short visits they flew back to the valley. Soon came the fourth baby eagle and YE was happy to have a little brother too. Mother owl was quite happy to have one grown and one baby sons. She did not feel lonely anymore. Now she was confident that while she is out for hunting YE will take good care of his brother. YE fought back against other eagles, falcons, hawks and the snakes which tried to sneak into the nest and take away his little brother. YE even cleaned the nest while mother was away. But when mother came then YE could take up any intruder no matter what size and from what family.

YE had a strange way of fighting. Usually he was nice and friendly to every one but when some one tried to hurt his brother or disturb his mother, then YE made a big scream and knocked him down in one attack. Therefore while every one liked YE in the valley they never tried to make him angry. 
It all goes back to the time when YE was a small boy. One day he crawled down the tree and got into a fight with a rooster. Mother owl was seeing every thing from the top of the tree The young rooster took the baby eagle as a strange cock with unusual long wings, big tilted beak, and little feet not good enough for running or wrestling at all, but yet the same size as he was.

The young rooster give him a big blow and the baby eagle cried while the chicken, the turkey and the dodo babies were laughing. The baby eagle, knowing that he is hurt and could not fight, decided to get back to where he belonged. He ran towards the tree and with the help of his beak and long wings managed to make it up to the top of the tree, where he faced mother laughing and smiling.

Mother owl said : Welcome home baby, what is the problem? There is no problem said the baby and you saw with your own eyes that the rooster hit me and you said nothing. While mother was still laughing she told him

You live in a big valley son! I wan you to live, survive and be successful just like your. father and don't look at me for help. I am an owl and as you see I stay mostly at home doing my own work. But you are an eagle's son. You have a long way and a tough life ahead of you. Stop crying !Otherwise if you come once more to me weeping because this boy or that boy has hit you, in that case you should better know that I myself will kill you not to mention your father: Eagles never cry, they only scream and attack. Remember that eagles also know who to fight, when to fight. Best of all, they know how to fight. And don't worry you are too young now. I am sure you would learn eagles' fight and can knock him off and a lot others too!

YE was growing fast and at 18 he already had become an exceptionally happy and handsome one. He was also known for his knock down attacks in cases of anger. Furthermore he had begun individual trips in leisure times and when parents were around.

Occasionally father eagle showed up but in irregular intervals. Their nest was not big enough for four, so YE flew to another tall tree and slept there. He came only next mornings to see Dad and listen to his wonderful stories. Dad was saying :

liA- Beyond the mountain surrounding the valley, there are dozens of other mountains each higher than the other. After that there is a large desert, where nothing moves under my sight on the ground. I know there are quite a number of snakes, scorpions, lizards and other small desert amimals and very few birds too, but mostly they hide under the sand or the bushes from the hot sun. However, I rush to the sea, where humbireds of fishes large and small, sweet and sour swim bellow or on the surface of the water. The sea is big, I mean very big. Some times I tried to cross it but no sign of an other land to set, so I flew back to the shore. After one year of flying back and forth, finally I found an lstand with high trees. I wonder if you guys want to go there some time, it would be wonderful! 
M()- Mother owl said: No never ! First of all, I can not fly that high and for such long periods. Secondly all my relatives are here in this valley:

H:- It sounds fantastic, however in case we go, mother would have to stay home all day long as we be huming sweet and som fish. Meanwhile brother is still too little for such jomney. He can't fly even to the next mommain yet, but I think someday we are going to make it OK mother?

Mo- Yes son, but don't get too carried away with your Dad's wishful talks. You have to finish school and college before reaching those dream lstands.

IA- Mom is right this is one thing I like about her. She is so sure in life that even she doesn't allow wishful talks. Your school and that of your brother is the only thing we are worried and are affer, no matter how much land, gardens and peasants we have.

They wouldn't help yon grow longer wings and sharper eyes which is edication. I mean building your own capacities and the right skills needed for being an eagle. Inless yon yourself are not searching and finding what is right and what is wrong, there is no other way so you become the best. Don't forget that eagles without wings must eat on piles of dirt.

All other birds liked the eagle family. Because they were pretty, neat, and helpful. The Eagles visited occasionally other families and help them with food, and if they had messages to be carried back and forth to other mountains and valleys, or they needed some medicine and other urgent assistance, the eagles were always there too help.

YE and lis growing brother were making good scores at school and doing what ever mother told them to do. Mother owl was becoming famous and stronger with tow young eagles under her command. She even looked after the harvest and the work of turkeys, dodos and chickens in the fields and in her gardens as well.

At nights before going to sleep YE often nurtured the thoughts of the Islands , the sea ,the deserts and the higher mountains beyond their valley. 


\section{CHAPTER TWO \\ An Eagle Fight}

Once YE tried to see some of the mountains that father had spoke about in his recent visit. He liked the tour as he flew higher and higher. Bèlow his big and strong wings he could see the largest trees like little bushes, the houses like match boxes and the turkeys like little ants.

There was a big green tree right at the top of the next mountain ahead and YE said that it must be a nice spot to set and see around before going too far away. As he got closer to the top, an other young eagle dashed towards him shouting and screaming. YE not knowing what is the matter tried to avoid him showing that he is not there to fight. Apparently his gesture didn't prove helpful and the first strike of the mountain eagle sprayed YE's chest feathers up in the air telling him how is going to be the second one.

YE still thought may be this is a crazy eagle and that is the way he greets the new comers, but yet out of precaution YE made a sudden swift move to take a higher position in the air and see what is going to happen next. In the second round the mountain eagle started a big hue and cry and many other birds and animals hearing the echo took a keen look to the sky where an eagles fight was gaining momentum.

The crazy eagle tried to use $\mathrm{YE}$ as a target spot or a prey and attacked in full speed from bellow. Now YE became fully confident that this eagle must be really crazy. In order to proof that he is still not willing to fight, he hovered in one spot but building spring-like momentum. As the crazy eagle came straight and got very fast and close, then YE simply jerked aside and the crazy eagle passed him like a missile missing its target.

For many viewers it seemed like the two were having fun. But YE knew that this stupid bird wants a real fight nothing else. As the mountain eagle was becoming mean and ferocious, many other eagles setting on the green tree give YE a big hooray knowing that he is skillful and is making a fool of the other eagle. Now the crazy eagle also knew that he had two vain attacks and the third one is going to be a mean one for him. But still though tired he prepared him self for the third round. The third one was not mean but a telling lesson. YE knew that not much power is left for the crazy bird and chose a straight fight. With a quick but strong blow YE twisted the mountain eagle and grasped it's head and tail and dragged him on the air as a large prey.

YE knew that the mountain eagle was an immature and rude fellow but had insulted YE by spraying his chest feathers up in clear blue sky. That was something YE couldn't forgive and accordingly he cut with his beaks the long feathers on both wings of the mountain eagle and then threw him on the air to catch it's missing wings. This was the funniest thing happening in an eagle fight that no one had seen in the air before. The mountain eagle couldn't keep it's balance in the air anymore and flew like a chicken going down and with funny flapping. He almost hit some branches of the green tree at the top of the mountain but managed to find the tree where his parents had nested below. 
YE made one more circle displaying his innocence and heroism. Then he slowly beamed towards the green tree where a bunch of eagles were awaiting his arrival. He greeted the family but couldn't hold his breath. His beaks were quite apart and his tongue was going back and forth in and out.

\section{CHAPTER THREE}

\section{In Love}

The mother of the family greeted YE back and said: You must have come from a long distance. We are sorry for the treatment of our neighbor's son. YE apologizing for the miss-happening said: I tried my best to avoid him, but he left me with no choice did he? At this time the daughter of the eagles family (DE) setting next to YE while giggling her glossy feathers said

DL- Yes I liked the fight. He deserved it. He thinks he is the hot shot in this mountain but has no manners at all. He always nake a big fool out of himself.

Yl;- I guess from now on he is going to learn how to treat guests, hopefully before growing new wings.

YE had not seen a young female eagle from such close distance before and was quite astonished by the voice of DE and found it mysteriously delightful. He give her a deep look and noticed her full grown complexion. The only eagle he had seen this close was his father and his baby brother. The long and shiny feathers on the shoulder and the big bright eyes of DE especially the pretty wings stretching in her sides made her outstanding in the whole family. While gazing at her, YE unintentionally whispered to himself: No wonder!

DY- Looking at her sides asked : Why? Any thing wrong?

YE- Not at all! I was talking abont your neighbor's son! Now I can figure why did he fought me. I bit he doesn't like even sparrows to come close to this tree.

I)E- Taking YE's comments as a complement asked: What about yourself, where were you heading any way?

Yl- Actually I was going to take a look at all the mountains father has told me about them.

At this time the father of the family asked:

IA- Where does your father live?

Yi- Beyond the momtains, beyond the desert, and beyond the sea in an Istand! 
Dli- Trying to catch YE's attention back to her said: Gi!

That sonnds wonderful, I didn't know there is a desert and a sea beyond these mommains.

looking at her father she said: I had never heard of the Island at all!

YE- Would you like to try some?

DF- Yap.

She said this and they both took off instantly. Before getting far the father yelled:

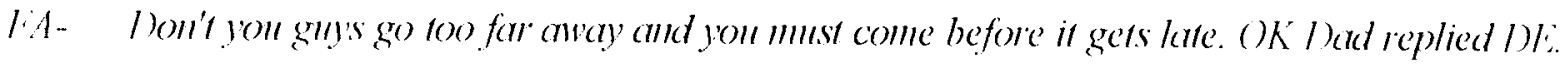

The journey began. DE flew ahead showing off her long wings, swerving tail and perfect body. But her eyes were tracing YE whether he was observant or not

YE- Are youflying or dancing?

D):- Both

Yli- In that case, while giving her an easy kick on the shoulder YE shonted: Are you ready for a surprise?

Dli- Yesss.

Yli- One wo three! And thus the race began.

A mysterious melody of joy was coming from the tip of their wings as the race started. The beats were getting faster and faster. The sky was becoming bluer and bluer and the milky clouds were passing one after an other. The race and the chase were so close and in such unison as if both were one entity.

YL:- How do youfeel babe?

1)l:- Wonderful, lets make it faster and faster!

Then they were passing through an other row of clouds till the green valley appeared beneath them with a white river dashing down the gorge

Pointing downward YE said: There! There! Do you see the silver fishes? Lets dive and get them. Then the two fastest creatures suddenly beamed down witl wings half folded like a pair of jet fighters dropped themselves straight towards the river. The drop became faster and faster as if they were two pieces of meteorites approaching ground from outer space.

Just before reaching the surface of the river their wings were opened and two pairs of claws smoothly grasped two silver fishes and then headed again towards the big blue sky, straight 
towards the clouds till the reached the peak of the highest mountain. There they sat and had their first lunch together.

Dl:- It was famtastic. I have never felt like this before.

Hi- Haven't you come here yet with your neighbor's son?

1)E- Iorget him, he is just a dodo, nothing else! OK?

He might think he is some thing but he isn't and I don't like him at all.

Yli- Has he ever told you how pretty your are?

1):- Would you please drop this. I told you he is out of it and can not dare to ask me things like that. And You too better be good! Because I don't buy cheap talks at all.

Y):- Look you are the only friend I have ever had. You also better know that down in the valley we don't hone different prices for different words. We say what our heart rell us. And our heart says what our eyes see. What ever both of them tell us is what we believe in. What we say or do is based on what we have seen and believe. Now tell me! Do you think you deserve only cheap talks and you are not a lovely girl?

1)Y- I don't know what to say. To tell you the truth I am not sure if I fully understood all of what you said. However I know one thing: those were the prettiest words I have ever heard from a boy. I can not repeat them but they echo like a piece of sweet music in my ears again and again.

Yl- Were they cheap or worthwhile?

Dl:- I think I will buy them all. And listen village boy! Here in the monntain we like the sun. Because it is hright, and warm and tells no lies. We are only afraid of winds because they come unexpectedly and go suddenly. We don't trust them at all.

Yl- What can a wind do to us here. It helps me going faster up and down!

1):- Come here close and let me tell you a top secret which I don't want the winds to hear.

Yl:- Who had never got that close to a girl before became red and shyly asked: what is it?

D)E - I wam the sun to be witness that, I, D.E. love a village boy named Y.E. very much. Is that $O K$ ?

Yli- And what else?

1)li- And I don't want the winds to hear this because tomorrow they w'ould tell every one about our most precious secret. You gor ir? 
YT- Yes I got it but now you made me very confused!

I) I- Why? Did I say any thing wrong?

Y7:- No but you said exactly the things I was going to tell you. Now I don't know what to say: I wonder how can I repeat my own idea but in your words?

DLE- Don't worry it is the same and you don't have to reply me now. I said what I felt to tell you . And you can tell me when ever you feel like it $O K$ !

YE- It is not OK. and it is not fair?

I)L- You mean what the sum has seen and the winds don't know yet, is not OK.?

YE- Not at all!

DE:- Andwe don't have a precions secret?

YT:- No, you are getting it wrong! What I mean is that back at the tree, when I san you first, my eyes told my heart that YE loves this girl and the sum was witness how I felt about yom. Go ahead, ask the sint, it doesn't lie. I swear I was not the second.

DL:- Yom mean yon were the first?

YT- $\quad$ Yes this is exactly what I mean.

Dli- In this case come close I want to tell you one more thing but right in your ear:

YE got very close and suddenly DE kissed him very close to the ear and asked: Now who is the first?

Yl:- You tricked me otherwise I would have been the first again.

I)E- You stubbom, you never give up, do you? We better get going it is getting late. Mom and load will begin to worry.

YE- I know but.

II:- But what? What do you want now, village boy?

YI:- I want you to write me a rain check?

I)I:- What is that?

YL:- It is only a promise! 
1)l:- lo dowhat?

Yt:- Promise that one day you would go with me all the way to the Island.

DE- How about that? You don't want much. Do you? YE! We need to get something straight and that is: You know that we have just met today and already we have come too far and too soon. We got to give it some lime. We shouldn't be pushing. Becanse it wouldrit work that way. To pass the mountains, the dessert, the sea and to reach your dream Island certainly takes several days, doesn't it?

Yl:- Sure il does!

D) i- How can l must you?

IF:- I promise I wouldn't eat you there, plus I am not a monster!

1)E- Silly I don't mean that, but certainly it would take some time before we take such long trips. I even don't know where you live and whom do you live with? What kind of friends do you have? I bit you must have a lot!

YT:- Not really, we live down the valley. I have an ow/ mother and an eagle brother. Dad is unpredictable. He comes occasionally and brings us plenty of sea food. Whenever he comes we have a lot of guests, visitors, parties and sometimes music and fun 100.

Dl:- It sounds wonderful but how come you call your mother an owl?

YL- She lived in a village and didn't receive any formal schooling to grow eagle wings that we have. But I love her a lot and she needs my help. On the other hand father as ant edncated person travels a lot.

DE- I see! I love to go and visit your family someday. But don't forget to come and visit us again. OK! And if you don't, you know' what happens?

YI: You would mark me absent!

()E:- Emm Emm!

Yl:- Then definitely you'd mark me sick?

1) Si- Shakes her head and tears circle her big bright eyes?

Yt:- Wait wait, I got it. You will miss your village boy, right!

While closing her eyes as sign of affirmative, DE feels the footsteps of a pair of hot and burning tears running on her rosy cheeks as she nodded. Her heart tells her that she is falling 
in love with some one whom she has just met in the very day.

YT:- Now listen DE! You are really' going too far and too fast! The fact you cry means you will mark me dead because in our village people cry only when some one is dead! You shonld also remember that I can't stand to see you crying. I will come to make you happy not to cry. Other wise I won't come again. If you want me to cone to see you again and again, then you should know that I woild only let you cry when I die not when I am alive. OK!

DI:- While cleaning her tears, smiles and goes closer. She hugs YE hard and whispers in his ears again: What am I gonna do with you!

Yl:- See, it is not fair, you are making scores and when I ask for it then there are excuses and time factors imolved.

Dl:- I am getting drowsy we better go before it gets too late, other wise my folks would throw me on the street.

Mi:- What ever you say! Ready for the second race?

DE- Yes, but be easy and no more sudden dives to the end of the valley, promise!

Yl:- Promise, one wo three Yahoo back on the air and straight to green tree.

Father of DY spotted them first as they were reaching closer to the green tree. He rumbled:

IA- How come DE is coming alone and what happened to that jerk?

Mo- Mother, while giving him a meaningful smile said: Old man don't jump to conchusions to soon. Open your eyes. They are flying synchro, something you have forgotten for ages!

As YE was saying goodbye to DE he also waved at her parents and shouted:

You have a wonderful daughter! I must run, Mom is waiting down the valley. 


\section{CHAPTER FOUR}

\section{Challenges}

Three years passed and YE and his brother were making good scores in every class. The turkeys, the chickens and dodos were bringing them wheat grapes as well as cash and they led a decent life in the valley.

Father eagle had many relatives as well as plenty of property, (land and gardens) in different parts of the valley. He and his brother Hawk had inherited this property from their father and yet not divided it between them. Hawk had one daughter the only child in the family whom played with chickens as there was no girl school in the village. Doctors had said hawk can not have any more babies thus he hated YE and his brother as well as their mother owl.

Hawk knew that according to Islamic law of inheritance, great portion of his and his brother's property will go to $\mathrm{YE}$ and his brother in the future. Because it was a custom in the valley that majority of the property of uncles without son must go after his death to his brother and his sons and a minor portion shall remain to his wife and daughter.

No matter what feelings apparently existed between the Hawk and his brother Eagle when they were young, but in these years that $\mathrm{YE}$ and his brother were growing, uncle Hawk was seeing them as the natural enemy of his family and thus tried to get rid of them by any possible but secret means. Thus in reality the Hawk, his wife and daughter had turned natural enemies of the owl and her babies next door, especially when father eagle was away.

On these grounds owl too used to take utmost precaution and knew that the hawks were the most dangerous and closest enemies to her children and yet their closest relatives as well (a mysterious norm which owl couldn't change). She also had no chance to convince the Hawks that neither she and nor her children had nothing against them.

Thus mother owl could never trusted the Hawks around. Especially after the doctor had said that uncle Hawk can't have further babies, owl had noticed that Hawk was giving baby eagles nasty looks and had a strange fear from them as they were growing bigger and bigger. By then Mother even didn't trust the food Hawk brought them .

It was an understanding between father Eagle and his brother Hawk that Hawk must look after their property, act as village leader and also supply what ever is needed by Mother Owl and her children while father eagle was away. However, in reality when father eagle was away the Hawk actually wanted to get rid off the baby eagle, but was afraid of the YE and his father and knew if they come they will kill him.

The Hawk nurtured very dangerous intentions but was only waiting for the right moment to come. 
One day when YE was yet in school, he came home and it was awful quite. Baby eagle had fallen to the foot of the tree. Up in the nest, mother owl had fallen fainted. Blood had covered all the long feathers and the face of his mother and little drops were still dripping even on the floor of the nest

Red, the whole world looked red and drowning in blood as YE looked at his mother's body and hot flesh still streaming to different directions. YE wanted to scream loud enough to make the world tremble. But he remembered that mother had forbidden weeping and crying for him as it was not an eagle's deed.

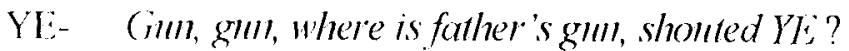

He soon thought there is no one left to give him a gun, he knew father kept it in a large closet. A long heavy gun at his hand YE shouted who has done this torture?

All the neighbors were extremely afraid and awfully quite. A weak voice of his little brother came from the bottom of the tree saying :

BR- The Hawks killed mother! They attacked me and then mother fonght them back! They are hiding now in their nest!

Though the gun was heavy and much taller than YE, however, he put a bullet inside and came to the balcony of the nest and aimed it awkwardly towards the Hawk's nest. The Hawk and his wife were running out of their nest. They knew this was the end of their game. The gun fired and hit the wall, just between the Hawk and his wife a big cloud of dust mushroomed

The Hawks left the village and soon neighbors gathered and mother owl, who was shocked with the sound of the gun, became conscious again and moaned awkwardly:

MO- What's happening ? Where is my son ?

YE_ Screamed: Mother are you alive? Thanks God Mama is alive!

MO- Mother raising up asked " Son are you OK ?

YE- Yes Mama and so is my brother. Get up Mother. It is all over now. It is your fault to hang around with hawks, chickens and turkeys. Your feet are not for walking with hen's and dodos. You got wings to fly. This is not your place to live.

An elder lady owl of the village came around and put a big bandage on mother's head and fixed her some boiled milk. She told YE

OL- It is not so serions, but son you need to be careful and talk to your Dad serionsly. The haw'k is the village leader when your father is anay. We know he has put so many traps around to get you and your brother". 
Yli- I can't wait for Dad and I don't care about him anymore. I'm worried when mother will recover.

Ol- In a week time! You don't have to worry. These are skin cuts and she would recover shortly. I don't think the Hawks would ever dare to bug her again but they are after you and your brother. You should watch yourself and your brother: You are faced with a mean and ricky uncle, who is after both of you wo.

Yl- Don't worry l have tanght of that too. I will hire turkeys, roosters and chickens to till our land and bring the havest to the city. 


\section{CHAPTER FIVE Moving to City}

A week later YE took mother and the baby to the mountain and rented a tree, close to DE's house where he also attends High School. Dad appeared home about two months later and YE began a argument with him. One day he plainly pointed to him:

YE-

Mad, I am tired of your stories, your big sea and your green Istand. You are an irresponsible husband. I think mother has been too good to you. You are just proud of yourself. You are selfish and want everything for yourself. Two of my brothers died due to your ignorance and arrogance. My young brother fell off the tree and had cracks in his skull and you were away for months. Taking advantage of your absence recently the Hawks almost killed mother. I moved our family to the mountain for the time being. I tell you one thing. I will come to the Island and may be find a bigger Island that you have nor seen yet, but l have to finish school and college first. We don't need your sea food amymore and your crowds and parties. Shist tell your brother to never cross us again. I'm somy for the shooting. I am glad they were not killed, but I swear that he would be dead if he give us more trouble.

Dad had gone to a deep thought, tears were running from his eyes and after a big pause he raised his head again and said:

DA- Son, you did exactly what was necessary to be done. I am proud of you. I assure you that the stupid hawks would never cross you again, otherwise I also will kill them with my own claws. The turkeys, the roosters, and the hens will bring you enough food and money for the rent and expenses. But make sure you should pay keen attention to jour school.

YE- I can't, I can not take the risk anymore. Is school important or my mother. I can go to any' school anytime I want to, but I camot find my mother any where in the world. Who will take care of mother and all she could do is to take care of home and us.

DA- It is my responsibility and she is my wife. I am somry that she could not go to places I go and do things that I do, but I was fooled by the hawks who had promised that they will look after the land, the gardens, and my family too. Apparenty they are double-crossing us and we don't need their nasty services anymore. So I am staying home as long as you and your brother finish your schools here. But when that is finished we must move to higher mountains, because there is no college aground here".

YE- That is great, I got to go for a short exercise.

MO_- I am glad you came to some terms with the boy, because I was worried you might be disappointed why we moved here. Your brother hawk has become very rude and has some 
nasty plans against YE. What ever he has been doing against me, I have taken it as a family matter, but lately he has been going too far and you should be aware of it.

On the other hand YE is growing impatient even worse. He shot them, but (jod did not kill them. It is time for you and me not to drag our problems so an immature boy should solve it. He has hecome too emotional and gives no chance to think before doing things. I don't want to put my son into such situations and such approaches by us is very risky.

Also he has found a girl friend in the Mr. Eagle's family next doors. You should talk to him that I don't like the girl. Someday they might disappear together like you and I may not be able to see them again.

I want him to get married with a chicken family so we can have full access to all the lands the gardens and onr fields. The Chicken's family are the largest in the village. Chickens are predominant, they are everywhere and I want good protection for my son.

DA- I don't know what's wrong with the Eagle's family. I don't think if YE likes the idea of living with an illiterate wife. He likes school and he is heading for higher edncation too. I doubt if he ever prefers to stay in the village and hang around with the chickens. Meamwhile you are right about Mr. Chicken's families. They are strong in the whole region".

M()- I have spent half of my life in your absence. I can not stand to be away from him. I think if he gets married with this family, I would see him, his wife and children a lot. And later if he goes an ay like you, at least I would hang around with his family and children.

DA- I can not push him and furthermore he listens more to you than me. I think if you persuade him I have no doubt he takes your word no matter what you ask him to do. By the way I like his attitude towards you, because my mother was very dear to me too. After all she was the one who arranged our engagement, didn't she?

Mo) Yes, but are you disappointed with her choice? Am I not faithful to you? Aren't you prond of me?

1)A- To be homest most of the difficulties that we are facing today is due to her arrangements of my life and she is not around to see it now. However as far as your faithfulness to me is concerned, it is the core of our family life and relation. And I am proud of you and your beantiful children. It is OK if we couldn't fly together up on the mountains, to the sea, and especially to the Island. But you have given a lot of love to my children and still I have a distinguished name in the valley and among relatives. Most of these achievements go to you than me. Even when I am away for months I am confident that you love me, my. family and treat well my relatives.

M( )- Let us stop bragging abont ourselves, I wamt you to arrange YE's engagement before you leave again. 
1)A- Well. I told you YE doesn't seem to stick aground in this valley too long. You heard him that he wants to find even an Island of his own in the vast oceans. It is too risky for me to argue with him in this matter. And I hope he is not too serious in his relation with Miss Fagle, other wise it would make things too complicated for your plans for his own schooling as well. Because he is in the last year of high school and he needs four more years to go to college, doesn't he? You must understand that I don't want him to get maried until he has finished college. At least this is my end of the line. Is that clear? Whom he gets married to, is his personal life and interest and I am sure he wouldn't nun down your choice and I wish you and him best of luck!

Dad said this and took off for a short flight till lunch.

The girl school inn the mountain was a gigantic tree at the top of a hill. Father eagle noticed from miles above that the boys school was dismissed and big flocks of walking birds and flying birds were going to different directions to their homes.

To spot YE was not too difficult for him as there were only few eagles in that high school. On the other hand YE took off fast and flew swiftly at a higher elevations where he barely flipped his wings, but showing off his strength, and body control. YE often used the winds of high altitudes and kept floating for hours. By doing this, he took keen look at anything moving beneath him.

Dad was interested to see what $\mathrm{YE}$ was after. He noticed $\mathrm{YE}$ was not going home. Because he was heading the wrong direction, towards the gigantic tree at the top of the hill. There he started circling slowly, smoothly and patiently. Dad noticed how big YE's wings have grown and how soberly he moves his head. His beaks and claws were exactly like him, but he knew that YE was still too young. Because it is not the habit of a grown eagle not to be aware of what is liappening above him. He said time will tell him to: look out for six directions if you want to be an eagle! Dad, too, began to circle as he felt something is cooking but he couldn't figure out what was YE exactly after. Soon the school bell rang and the girl school, too, was dismissed. Suddenly a pretty white eagle, wearing school uniform, came straight to $\mathrm{YE}$ and stroke each other on the shoulder as the sign of an eagle greeting. Soon they wiggled and whistled and YE said "One, no, three, and yahoo". The two prettiest creatures got such a speed and passed Dad in such a haste that if Dad hadn't moved aside, they would have clashed with him in wide open sky.

Jesus! So this is youth, saying this father went to some old memories. He took another glance down to see if the rest of children are heading for home. Then he wanted to chase the two crazy eagles, but it was too late. They were out of sight and even out of this valley. Dad gave up and decided to better make it for lunch with the family. They had not fully finished lunch when YE appeared while taking deep breaths. Father pretended that as if he has not seen anything and asked: 


\section{CHAPTER SIX}

\section{Engagement}

FA- What's the matter, did you have to run from the school?

Yli- Yes Dad, the teacher gave an assignment after school bell rang and we had to write them down from the board. Sorry for being late!

IA- Father smiled and said "I hope you have not missed some of the important questions writing them in such a haste.

YLi- No, I jotted them down one by one.

liA- Good for you son, have your lunch. It's a delicions soup.

Yl:- While assuming Dad must have seen their after school flight, asked : Even more delicious than the soups in the Istand?

$D A$ - Knowing that the boy is being sarcastic wanted to convey a family message indirectly and said "Yes, honestly your mother cooks the most delicions dish than any where, except the soup I had the other day in Mr. Chicken's family. It was exceptionally a good one!

I't:- The ('hickens!, Yeah, I doubt if they know even what is a good soup? They eat any thing and every thing found around. I like fresh hunted meat, something that you could not find in the nest of any chicken".

MO- Son! We are talking about Mr. Chicken's family and you better mind your language.

YF- Yes Mother, I am sorry!

YE realized that there is something odd about father and mother today and especially their questions and comments were strange. Especially YE wondered why mother was upset with his comment about the Chicken's and what this had to do with Mr. Chicken's family. He knew mother visited them often, but couldn't figure out what was in mother's mind. In order to get a clear message, YE said:

Yli- Mom, let's go for dimmer to the Fagles and after dimmer we all can come back home. How does that sound?

Mom and Dad looked at each other and Mom said: 
10_- No, tomight we are staying here and we have a lalk with Dad hefore he goes back. We have a lot to do.

VI:- Why don't you and Dad do it and I go for dimer to the Eagles' and join you later:

BR- His young brother laughed and said: Crazy!

YE was surprised that something fishy is going on that even his young brother knows but he doesn't. A bit embarrassed, he touched mother on the back and said:

I7:- What is going on Mama? What is in your beantiful head? Spill it out. Have I don something wrong which has made you upset?

10)- Yes, you are putting you feet at the same trial as your Dad. The man has a family, land, and property, but spends most of his time in an Island that not many have seen. And yon, too, are spending much of your time nowadays in the air, than the ground. I am getting tired of it

Yl:- Lasy, easy mother, take it easy. Don't cry. You know that we all are doing our best to keep you happy.

MO_ I am not talking about all! I am talking about you, no body else. You don't love me, and somer or later you are going to leave me, like your Dad.

YT- Stop crying I have nothing to say about Dad, but I swear to God Almighty that there is nothing in the world so precious to me as to keep you happy. If you ask me to commit suicide, I will do it, just to keep you pleased. Now tell me what is it that you want me to do. Is there anything that I can do to make you happy? Just tell me.

YE getting a bit scrious, turns to Dad and asks: Dad, will you please tell me what is going on? I am getting frustrated and you all see mother is weeping.

The little brother acting smart said:

BR- I tell you what is it, but give me a five first.

Yl- OK assume you have gotten it. I promise!

BR- Promise?

Yli- ()K, take my words for it silly!

BR- Well, Mom wants you to stop seeing Miss Eagle.

YLi- OK, and then? 
BR- Then she wants you to hecome engaged with Miss Chicken.

YL:- And then?

BR- Then she will he happy.

Yl:- Feeling stranded asks: Is he telling the truth mother?

MO_- Limphatically siressed: Yes.

Yl:- Burst into a big laughter and said: Well, well, well! How about that ! And what do you say Dad?

I)A- No comments, its your life and your decision. I am out of it!

YF- (OK mother; you are getting serious. As far as life is concerned, I know one thing for sure and that is that I have no separate life from you, hut as far as Mr. (hicken's family is concerned, I wonder if yon have given it a deep thonght. I believe she has not seen the door of school and will get lost in the first city she enters. Thirdly, all I know about chicken's they lay eggs here and there, every where and have no pairing style.

At this time mother spoke loudly and confidently and said:

MO) I I am not like you. I think much before what I say. I know you and your father's family well. He is away most of the time and most of his relatives, inchiding uncle hawk and uncle falcon are after you, because all the roosters and chickens do what you tell them to do, not what your uncles tell them. Someday your uncles are going to cause you and your brother a big trouble. Neither me and nor your Dad want that to happen.

WF- So yon are afraid of the hawk and want the Chickens' big family to defend me in the sky. Well mother to bee honest I am not afiaid of the hawks and falcons. What I care is you. All my life, I murtured one desire to make you happy. But still can I ask your view about Miss Eagle too.

MO- I think she is too nice and too pretty, and she will take you away from me, your brother and our land and property. They always live up in the mountain and they are going further away from the land. But I want you to be close to the land and I know that with the big family of Chickens you would be staying in the valley.

Vl:- I respect what you say mother and you don't have to give reasons, because one does not stuport the other. Inst tell me what is your choice.

M()- Miss (hicken and nobody else.

Then the YE crying silently for the first time in life looked at her mother's eyes, and said: 
YL- Mother, you have told me a lot about how Prophet Ismaeil wem with his father to be sacrificed. I also have one life and it is yours and I have no other desire superior than to prove that there is nothing in the world as dear to me as your consent and happiness. But remember mother I have wo wishes in this sacrifice.

1- I have sacrificed my body and I can not sacrifice my soul as it belongs to Miss Fagle and I shall not be blamed for it.

2- You can go ahead with the engagement but I am not going to get maried till I finish college!

Then YE raised and kissed Mom on the cheek and said

Mama, I love you and I thank God that I was able to fulfill one of my earnest goals. What ever the oncome maybe I assure you that I never break my word of honor with any one, especially with my parents:

Dad was weeping and the young brother was drowned in mixed feelings. By then it was 10 PM at night and the moonlight had given a silver color to every thing. YE was feeling very uncomfortable and a pain originated in his own family had destined his soul and body to go on separate directions for the rest of his life. He didn't know what to call it. Death ? Certainly not, because he was breathing. Life? Not at all because life is full of hopes and for him there wasn't any left. YE tried to feel the soul of Prophet Ismaeil but found out that he was rescued by a niracle and a sheep was slaughtered on his behalf. 


\section{CHAPTER SEVEN}

\section{The Soul Trip}

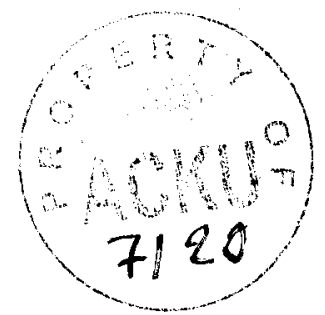

However, a storm was building up inside YE like an unseen volcano. He knew he is going to burst sooner or later because his soul and body did not belong to each other any longer and this was the core of the fire burning him inside. He needed a big body of water to dive in and get a relief at least for the time being.

He knew only a miracle can rescue him from this storm nothing else. But yet there was no sign of such miracle to come. YE took off instantly without telling a word. Nonchalantly, he headed towards the tree at the top of the mountain as if he was looking for a fire station to stop him from burning.

Before reaching the tree he spotted the white ring circling DE's nick setting on the roof of their nest. When DE spotted YE approaching she too took off silently and joined him with a kick on the shoulder as usual.. It was the calmest night in the universe. There was only the moon and two wanting souls floating on the air miles above the valley.

DE- What is going on tonight? Inside me I feel something terrible is happening to you. I swear to God, mimutes before you came, I was awake and had wired thoughts as if some one was torhuring you, cutting you apart. I was trying to help but as if I had a nightmare and couldn't do any thing ahout it. I thought I must do some thing. So I took off and came to your place and to see what is actually happening there. You wouldn't believe I did so, Do you? I am sorry! I told you I was feeling anful inside and all I wanted was to find you in one piece and alive nothing else. And when I peeped through the window I saw all four of you having tea. livery body was looking at you and once you raised and said some thing to mother. I couldn't get the first part of what you said. The door was closed but not fully so I put my ear at the open edge and could hear you saying: As far as my soul is concerned, it belongs to Miss Eagle. I was so proud of you and while the moon was witness I repeated to my heart: I, Miss Eagle ,Confess to God Almighty that: My soul \& body, My dreams, \& thoughts, My presem \& futhre, My tears \& laughter, My joy \& sorrows, My anger \& pleasure. In each moment of life When I am young or old, Awake or asleep, Healthy or sick, Belongs to Young Eagle, Only to him ! Again I peeped and then you raised and kissed Mom. I felt so proud of you. I have seen no one loving his mother as much as you do. Meamwhile I was glad it was her and not an other girl. Other wise I would have been pissed off.

YI: - Yes you saw almost every thing but you didn't hear every thing.

1)E: - I don't care what I missed but there is no better way in love than giving your soul. Body is nothing and doesn't mean any thing. 
Do you think those who get old can not love anymore?

Do you think those who are not pretty have no heart?

I think the prettiest part of life is sonl.

Soul rules over the body.

Without soul body is a piece of rock with no sense at all.

But even then, despite seeing yoi and hearing all those sweet words, my heart was giving me messages which did not match with what I had seen and heard at your place .

Now tell me what is really happening? You seem awful quite and sad 100. I can rell something terrible has hoppened.

17:- No Nothing is happening anymore! It simply has happened.

DY- What happened? When? Where? I saw you after school today didn't I? You said nothing about it!

Yl:- II didn't happened then. It had happened mimutes before you had peeped through our window.

1)Y- OK.. That was an hour ago and I saw with my own naked eyes and heard every thing. They were fantastic, then something must have happened on the way coming here.

YLi- No! Lets take it easy. I want you to relax.. Stop flying. Let your wings straight. Let your soul float to the endless world leading to the heavens. Try to feel as if we have no body. no wings, no tail and no claws. (lose your eyes and then allow our souls to mingle.

God knows how long this soul trip had last and at what speed and where the winds had taken them. After a long ecstasy DE spoke. 


\section{CHAPTER EIGHT}

\section{Salvation}

Dl:- Siweetheart I did all of what you said, but I feel dizzy. Lets go down I might faimt. I feel weak, just hold me tight. It is getting too cold for me, I am practically shaking.

YL- . Just get on my back and relax. We are descending.

For a long period, full silence prevailed. YE wondered :

How long his new relation with DE would last?

How DE might take these crises?

What features would his relation would take with DE?

And how would it affect her?

How would he spent the rest of his life in Chicken's nest and dreaming of YE?

Would they be walking or flying ? For how long and where to ?

What will they eat what will they talk about? What can they do and where they could go together.

He simply answered himself: Since I belong to my soul, it wouldn't matter what happens to my body. It would be like a piece of rock for Mama and Miss Chicken no matter what will they make out of it.

Suddenly he noticed a big ocean beneath and an Island ahead. The only thing moving was the dazzling white waves washing the shores joyfully. He whispered in DE's ear :

Yli- We are approaching a sandy coast but I am not sure am I dreaning or is it real.

Dli- Does it make any difference? Tonight I am in a mood to lay in the sand and stretch my body so I can feel every little bit of the sand caressing me. And I want you to give me a message so blood start re-running in my veins once again.

After a while she requested: Let me down there and let us watch the tides, I bit every one of them welcome us to the Island. I am glad we finally reached where you wanted us to get one day. It is the prettiest place I have ever seen: calm, quite and you and me, all by ourselves. Isn't it the Island you got my rain check for it?

Yl:- You must be right!

DY- And you don't think it is right?

Yl:- Right. 
1)l:- And if it is not right then it must be wrong .

Yli- Yes it is wrong.

1)t:- What is wrong? Are you ont of your mind? You don't make sense tonight. Up in the sky in your soul trip I got dizzy and don't know what happened and how did we get here. But now' that we are here, in your dream Island, I am going to stay here and raise our children tight above that tree. Right?

Hi, Wrong!

1)I- While holding YE's hand started slowly walking along the coast and continued: Lets get one thing straight. YE listen to me carefully: how can some thing which seem so right to me to night be wrong to you? It couldn't be true right?

Yl:- Wrong!

1):- Last week in our logic class there was a topic which said: Unity of conflicting phenomena at one time is impossible.

This means some thing can not be right and wrong at the same time. Now according to this some thing is definitely wrong either with your way of thinking or mine. And we need to spill it out no matter who is right or who is wrong. Other wise some one is going to ger hurt. And further more, love only asks, for right and never supports wrong things .OK!

Do you agree?

Yli- Yes; I fully Agree.

Dli- Good, Now let me get things straight! YE. Tell me plainly: Do you still love me?

YL:- Much more than ever!

1) Hi- Then don't you want me anymore?

HI:- Noldon't!

D):- How that can happen? It couldn't be true right?

Yli- Wrong!

1)1:- You do love me, but you don't want me, correct?

Yli- Correct!

I):- In this case some thing is certainly misunderstood. 
Yl- You are misunderstood.

DE- About what?

YE:- The message you had heard while peeping at our window.

I):- You mean you were telling lies to your mother and what I heard then, is not mue?

Yl:- What I mean is that you had not heard the message fully!

1)E- And what was the full message?

Yl:- It was: Mother, I love you and respect you very much. Just like Prophet Ismaeil, you could take my body and do any thing you want to do with it. But, as far as my soul is concerned it belongs to Miss Eagle.

DE- And Mother bestowed that too to Miss Eagle.

Yli- No, she gave it to Miss Chicken. Tomorrow she is going to slanghter me formally and announce our engagement.

D):- Do you love her?

YT:- Not al all and never did?

Dli- Doymhate her?

Yli- Not at all.

Dl:- Then you are a big piece of rock!

YE- Exactly like the one you described in our soul trip.

DE- Congratulation!

Yli- For my engagement?

(1)L- No!

Yl- lor what then?

DE:- lior the second slanghter.

Wli- Second slanghter? 
1)L- Tell your great mother that she did not only slaughter you but me and my life too.

DE burst into crying and continued:

Tell her she simply burned both of us inlo flames and ashes. I respect her a lot, but surely in the dooms day I shall grasp her arm and ask:

Why?

Why did she do this to us? To her own son.

Why did she ake revenge of her own life from us?

Why did she turned us to two solid rocks, to two statues that love each other but shatl not touch each other until dooms day. She had baby eagles but did not allow us to have ours'.

She lact a prideful life, but didn't want us to be proud and happy:

For a few minutes she wept silently and then shouted:

Is anybody there?

Canl anybody see us burning?

Then she turned her face to the sky and screamed loud:

God! Are you there?

Can you see what is happening to us?

Is that what you want?

Is that what you created us for?

To see us in tears, falling apart?

Are we your worst statues?

Do you want to destroy us?

And make an other?

What was our fault?

What if things go wrong again?

Who created love?

Who taught us love?

And why is it yet so sacred and dear?

She kept crying for their own memorial ceremony. Then YE touched her on the shoulder and whispered in her ear:

YL- Calm down DE. You are going too far. Let our soul be in peace. Let God do as he wishes. At least he will be happy. Don't cry. You know that you were the only one I loved and still are the only one ! OK?

1)t:- If I don't cry tonight then when should I cry and what for?

V:- DE! I love you and keep loving you till the last breath of my life!

Then they went for a long silent walk side by side. Their foot prints inscribed on the wet 
sands: Love lasts For Ever !

At one point DE moaned and while leaning on YE said:

DL- I feel weak and a chill again. Honey, I got to lie down, hold me tight. Then she fell by her side and said I need a blanket.I think I am dying, and if I don't wake up again, remember I love you my village boy very mich! OK?

YE stretched his wings to warm her and held DE's head on his chest. Soon he felt a sharp stream of hot and burning tears soaking just above his heart. He new many things in life but couldn't figure out that : Does tears belong to soul or body. If it was part of body then why doesn't it come often and regularly. And if it is part of soul then why is it in the form of liquid. Soon he discovered that he was crying too, something that eagles were not allowed to.

Yl;- Talking to himself silently: No it couldn't be true, I have a heart and I have a soul too. And eagles must cry when their soul is in pain. Othenwise nothing else can heal or at least stop this pain temporarily.

They both fall asleep. The calm beach and the moon was witness. Early in the morning DE heard the sound of an eagle's wing and got up finding YE still sleeping beside her. DE wondered, there must bee some eagle around peeping on us. Then she yelled at YE

I):- Wake up. We gol company.

YL:- Raised up saying: Where we are ? And what is happening ?

1):- I am sure I heard the somd of an eagle flying close to us. I bit some one is spying on us! At least I know' we are not the only couple here. You need to wash Breakfast is ready, sweet and sour fish but we must get home before school hour.

As YE was washing his face DE continued:

D):- I don't know about you and your future split personality. As far as my side is concerned, I think school would become my best scapegoat from reality. I know I belong to you for ever. Whether you slaughter me like your mother or take me as your God given right. But I also know that I can't have you and the only thing I can substitute your presence with, must be reading. Reading all the stupid books, laws and regulations written about decent marriage, prideful life and so called sanity. I think this world is full of crnel and aggressive people who make fun of others and take a joy and pride by hurting other vulnerable people like us who are doomed to be sacrificed as loyal obedients.

Blind obedients are consisted of wicked and vulnerable people like me and you who feel obliged to follow the rules written or non- written and to live up to others expectations. It becomes ridiculous especially when people like us, the hurt ones or the victims, find no one weaker and then they take all these pains of life upon their children and call it as their code of laws for ideal life, love and marriage. 
11: While listening carefully to DE said: Do you mind if I repeat what you said two years ago when we had our first lunch at the peak of a mountain close to your house?

1)1: Not at all, I wonder what would it change?

YL: I think these were some of the best words I had ever heard from a girl in my life. I wish you were my attorney last night at my house when my life became doomed to burning for the rest of my life. By the way DE! ! Have you noticed these foot prints?

1):- No! Where?

Yli- Look these belong to us but what about the other three pair of claws. One big, one small and one medium. I think there is an eagle family and have taken their morning walk just by the place where we had slept last night.

After a while YE starts again: I have a wired feeling and I hope you don't make a fool of me. I feel Mom and Dad have been here and these foot prints belong to my brother.

Dl:- You must be day dreaming or still are on your soul trip. We better go hefore it gets late for school time.

Y:- But I have a strange feeling this morning. I feel very different from last night. He gave a warm hug to DE and continued: I don't know what has happened last night. All I can remember is when you were fighting God for yourself and for me. Then I fell asleep. But this morning something strange must have happened, maybe a miracle, that we don't know.

I)L- like what?

YL- I feel that God is willing to give us tow daughters like you and wo sons like me in this land of paradise.

Right then they grabbed each other and rolled down towards the edge of the coast. Just before rolling to the sea, they were caught with the claws of a young eagle, who stopped them from falling to the water. It was YE's brother, who said:

BR- You guys are great! Get up! Everybody is watching you! Look up at the tree and see the crowd. Cant you count them? There are one, wo, three, four, five, six, seven, eight eagles: There, the smallest is mother owl. We all came last night, after you guys disappeared at 10 PM.

IDE I know the two are your parents, who are the rest?

BR- The rest is your family, can't you recognize them. Your mother came at eleven at our home 
and asked whether you were at our place. My mother said no and YE too is missing since 10. Your mother said YE approached our home slightly after ten, and I was the only one awake, but I didn't know DE was waiting for him on the roof. They just flew and disappeared. Then my father said they must have escaped to the island. So we all said "Let's go, and find them". On the way, we were caught up by a strong wind. We only tried to stick together, and the wind blew us right to this coast, where we found you asleep side by side. (iness what mom says. She says I am mot leaving this island anymore. She wants to raise her grandchildren here .

1): - What abont my parents?

BR - They say, we want to live, wherever pleases DE.

17: - Oh God, am I dreaming? Is this real?

DEL - Quit talking to your soul silly, lets go and welcome our first guests.

They all dashed towards the big tree. There was hugging, crying and screaming, as well as giggling and wiggling.

MO - Mother owl kissing DE, said: You are so sweet and beautiful. I am glad that you guys opened my eyes. Especially your last night's prayer to God was strong.

The fact you said that you would be asking me on the doom's day for what I have done to both of you, was something that I could not answer to God on that day. Thus we kept crying last might together with you. YE's Dad didn't want us to disturb your harmony.

But today all I have for you wo is :

\section{Birds Of the Same Feather, Shall Fly Together}
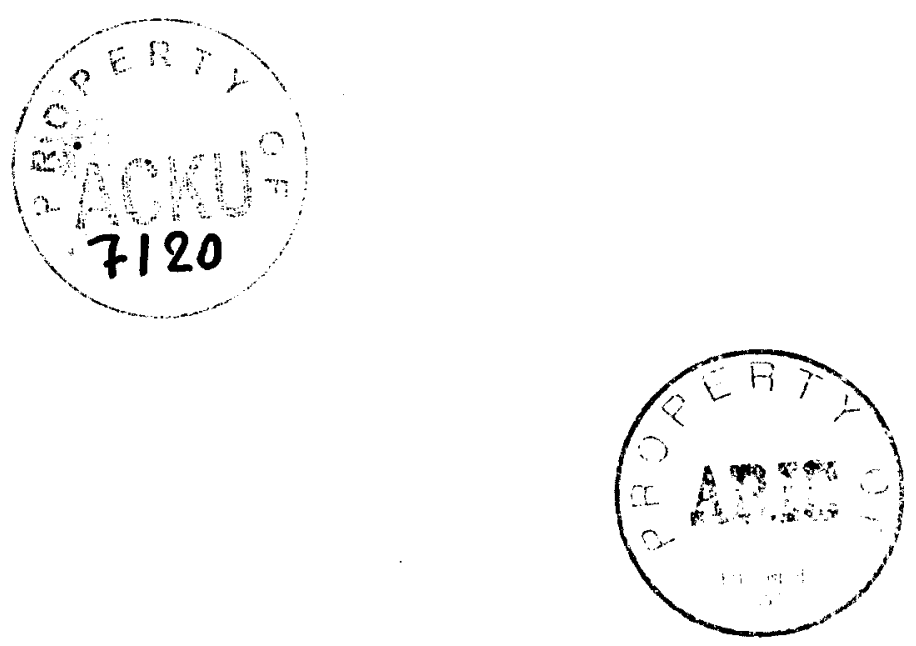